\title{
Notes from the Playground
}

The Educational Process Between Contingency and Luck

\section{Maura Striano}

\section{(2) OpenEdition}

\section{Journals}

Electronic version

URL: http://journals.openedition.org/ejpap/1902

DOI: 10.4000/ejpap.1902

ISSN: 2036-4091

\section{Publisher}

Associazione Pragma

Electronic reference

Maura Striano, "Notes from the Playground », European Journal of Pragmatism and American

Philosophy [Online], XII-1 | 2020, Online since 16 June 2020, connection on 26 June 2020. URL : http:// journals.openedition.org/ejpap/1902 ; DOI : https://doi.org/10.4000/ejpap.1902

This text was automatically generated on 26 June 2020 .

\section{(c) (i) $९$}

Author retains copyright and grants the European Journal of Pragmatism and American Philosophy right of first publication with the work simultaneously licensed under a Creative Commons AttributionNonCommercial-NoDerivatives 4.0 International License. 


\title{
Notes from the Playground
}

\author{
The Educational Process Between Contingency and Luck
}

\author{
Maura Striano
}

In his autobiographical writing Trotsky and the Wild Orchids (1992 [1999]) Richard Rorty vividly describes an emblematic episode of his adolescence that has a specific value in terms of his educational reflection: when he was an adolescent, bullies regularly used to beat him up in the playground of his high school, an action that he was unable to avoid. This scene, indeed, portrays a recurring theme of his school life, which assigns predefined roles to different actors - the bullies and their designated victim - and it is, therefore, a good example of what Richard Bernstein would identify as one of the many "concrete social forms of cruelty" (Bernstein 1992: 287) that we somehow take for granted. On the other hand, Rorty's narration of the episode effectively illustrates what Rachel Haliburton acknowledges as the capacity of the liberal ironist to provide an effective re-description of "what humiliates," drawing this from a personal awareness of the various ways in which human beings can be humiliated (Haliburton 1997: 56). Indeed, as Rorty points out in the introduction to Contingency, Irony, and Solidarity (1989) 'for liberal ironists, there is no answer to the question 'Why not be cruel?' - no noncircular theoretical backup for the belief that cruelty is horrible. Nor is there an answer to the question 'How do you decide when to struggle against injustice and when to devote yourself to private projects of self-creation?"' (Rorty 1989: xv). This decision is a matter of contingency, and has to do with what Rorty defines as "luck." The young Richard decides to "escape" from the humiliating situation he was trapped in by seizing the opportunity to leave ordinary high school in order to attend the Hutchin "college" at the Universiy of Chicago, thereby starting to re-describe his life project according to a new and different perspective. Through his narration of this episode Rorty invites us to acknowledge the capacity that each individual has to create and re-create one's self, diverting one's path away from expected roles and performances defined according to a predetermined script, which reflect the contingent requests of the public dimension in which individuals are embedded, and overcoming the dialogues and narratives one may feel trapped in. 
From a pedagogical point of view, this is a crucial point, since it reflects the relationship between the individual and society and has to do with what Rorty in Philosophy and the Mirror of Nature (1979) describes with the term "edification," which is a substitute both for education ("a bit too flat") and Bildung ("a bit too foreign"), indicating a process taking us "out of our old selves by the power of strangeness, to aid us in becoming new beings" (Rorty 1979: 360). Edification implies a profound redescription of one's life conditions and represents, indeed, for Rorty, the only possibility of escaping from, but not overcoming, cruelty and humiliation, since there is no way to convince whoever performs cruel acts of the inappropriateness of this behavior, if she/he has been raised with the conviction that such acts are permissible in a determinate social context or if they are, for some reason, rewarding or satisfactory. As a matter of fact, the environments within which individuals and communities grow up and, in particular, the conversations and discourses in which they are embedded, as well as the linguistic habits they are used to, make the difference since they shape the core of one's being in the world, identified by Rorty in "conscience and aesthetic taste," which, as he explains in Trotsky and the Wild Orchids, can be considered "equally, products of the cultural environment in which we grew up" (Rorty 1999: 15). Cultural differences are so deep and strong that there is not, and there can never be, any neutral "common ground" to which individuals, who have different forms of conscience and esthetic taste, can "repair" in order to argue out their differences (Rorty 1999: 15); we need therefore to acknowledge the incommensurability of different life stories and narratives, which are the by-product of different processes of inculturation and socialization but, as Rorty points out in Universality and Truth we should also be aware that "there are not incommensurable languages" since "any language can be learned by one who is able to use any other languages" (Rorty 2000: 18) which means that people can always overcome the communicative barriers determined by the use of different linguistic codes by making new hermeneutic moves. This requires a move away from what in Contingency, Irony, and Solidarity he describes as "common sense" language, which refers to the "final vocabulary" individuals "are habituated" to use (Rorty 1989: 74). According to Rorty's vision, when people refer to common sense linguistic structures there cannot be any possibility of a reflective encounter of any kind based on rational argumentation, on the basis of the possibility of performing what Jürgen Habermas (1990 [1983]) would define as a form of "communicative action." For this reason, Rorty is extremely critical of Habermas' reference to a rational frame of reference according to which individuals can dialogue and communicate, beyond cultural constraints. Accordingly, as the American philosopher points out in Philosophy and Social Hope, if there is no shared ethical and esthetic understanding of the world, conflicts and quarrels of any type cannot be overcome through argumentation and reasoning. Under these conditions, therefore, there can be no way to negotiate with the bullies we encounter on the playground of our life in order to understand their reasons, and to make them understand ours.

Within this framework, individuals who have different cultural, economic, political and social backgrounds and insist on affirming their ideas on the basis of a universal idea of truth, referring to established frames of reference, will always "strike one another as begging all the crucial questions, arguing in circles" (Rorty 1999: 15), systematically descending into fallacies, attempting to prove any proposition while simultaneously taking that proposition for granted. In Universality and Truth Rorty makes a distinction between "arguing with people" and "educating people" in order to point out the 
ineffectiveness of rational argumentation within a specific communicative context (Rorty 2000: 19). In Rorty's view, the point is not only that argumentation is not effective but, as Susan Dieleman points out, "argumentation does not break out of the established conventions, and because novelty is required for social progress, the motivation must come from elsewhere" (Dieleman 2010: 893). The solution is, therefore, to elaborate alternative forms of communication and expression, which could have more effective practical outcomes, but this can happen only if people move out from the conventional realm of the discourses they have been used to, and start to re-frame and re-describe their world in new and different terms. Again in Universality and Truth Rorty points out that what cannot be achieved on a rational basis through argumentation could be achieved through an "appeal to sentiment" (Rorty 2000: 19). On this basis he also grounds the possibility of using "non-violent means to change minds" (ibid:: 20) by stepping into a different discursive context, which has deep pedagogical implications.

Nowadays, primary and secondary schools are at the crossroads of different cultural instances and experiences and cannot be seen as the safe place within which individuals can be engaged in reasonable conversations and discourses through which different cultural traditions and different vocabularies can be harmonized within a unitarian democratic educational project. This is particularly significant if we acknowledge, as Rosa Calcaterra points out, how there is "an evident asymmetry between the convincing discourses provided for supporting the principle of cultural pluralism and the concrete dynamics of the socio-ethical reality of our time" (Calcaterra 2015:5) which, I believe, is a very delicate point in reference to educational contexts. Within our globalized societies schools, are, indeed, the melting pot of conflicting instances and are the ground on which individuals with different experiences, opportunities and stories come to interact and grow together, being continuously faced with the impossible but fascinating task of sharing incommensurable experiences through incommensurable narratives and vocabularies. Moreover, the playgrounds of real schools are the foreground of the encounter, often conflictual, of youngsters whose educational possibilities are conditioned by their cultural and social backgrounds and life histories, which are incomparable and unique but still need to be taken into account in order to be explored and contrasted with other possible expressions and narratives. In this context bullies and their victims can reframe their relationship only if they have the opportunity to develop a deeper and wider vision of individual and collective experience, which would allow them to be engaged in other and different discourses, to re-describe the world in new terms and to share their re-descriptions through multiple narratives. As Tracy Llanera explains, this can occur only on the basis of an involvement in some kind of "redemptive relationship" and of an encounter with alternative lifeworlds (Llanera 2019: 27), which is a crucial educational issue.

According to a Rortyan approach, what should be first of all cultivated within educational contexts is not the capacity to argue, communicate and reflect on a rational basis, but rather the capacity to listen, to describe and re-describe, and to use different and even new forms of language and new words in order to create new narratives and re-write the scripts individuals have been referring to. In this perspective, individuals come to have the possibility of developing peculiar capacities of re-description that are mobilized essentially at a private level but, and this is my point, require to be developed at a public level. As Rorty points out in Contingency, Irony, 
and Solidarity "the vocabulary of self-creation is necessarily private, unshared, unsuited to argument" and therefore it cannot be "a medium for argumentative exchange" (Rorty 1989: xiv) but, rather, it can be a tool for a new understanding of the world that other individuals may be challenged to use. As a matter of fact, this is one of the most controversial points in Rorty's scholarship due to his insistence on the necessity of separating the private from the public dimensions of human experience. This separation is, indeed, particularly problematic from a pedagogical point of view since it would mean that the educational experience and its outcomes are essentially contingent, private and personal and therefore they cannot be designed and planned in advance, nor can they be considered to be for each and everyone. Moreover, since education is a public endeavor, it makes use of shared experiences and resources and makes use of public spaces within which the process of self-creation becomes visible and tangible.

As a matter of fact, in his Intellectual Autobiography Rorty pointed out that there is no "barrier" between the public and private spheres (Rorty 2010: 21) but that private projects are often not relevant to an individual's public engagement, which occurs on a different basis. Indeed, as Tracy Llanera notes, there is a common feature that connects the two dimensions, which can be described as self-enlargement, since both selfcreation and solidarity enlarge the individual and collective experience (Llanera 2016). From a pedagogical point of view this feature could be the basis of an educational project which could refer to private experiences of self enlargement that could be shared and developed within a public dimension. Along a similar line of reasoning Michael Bacon notes that if in Rorty "self-creation begins as a private matter, it need not end there," meaning that individuals, through the process of self-creation, which is strictly connected with Rorty's notion of "irony," come to offer re-descriptions which have a social impact since they "call into question received wisdom" and draw attention to "unnoticed forms of cruelty" (Bacon 2017: 961, 962). As we can see, the main focus of Rorty's idea of "irony," which is the tool that individuals use to redescribe their references and their world, is cruelty and in particular, those forms of cruelty that are accepted as legitimate within a cultural, historical and social context, like the cruelty of bullies who attack a child in the playground, or the cruelty of the German soldiers who shared responsibility for the Holocaust. Accordingly, the main outcome of a process of re-description and self re-creation, at an individual and collective level, is therefore the capacity to detect and overcome cruelty within different kinds of human experience, which can be identified as a relevant educational goal. Within this framework, one interesting point to discuss is, therefore, whether individual capacities of re-description can possibly be used as a reference at a social and public level and what their educational impact could be, taking into account cultural and contextual differences. Let us think, for example, of the educational impact that the reading of Anna Frank's diary, a very private and individual document that was not meant to become public, has had, and still has, on the consciences of thousands of adolescents since its first publication.

Rorty's separation between the private and the public is emblematic of what in Contingency, Irony, and Solidarity (1989) he acknowledges as the "contingency" of individual and social experience. In order to clarify this point we can refer to the reading of the Rortyan thesis of contingency offered by René V. Arcilla (1993), who highlights how it is mainly based on "the freedom of re-description" which enables us to "celebrate what distinguishes one's self from others through the exercise of irony" 
(Arcilla 1993: 202). As Daniel Conway (1991) points out, in Rorty ironic self creation is "exclusively a private affair" which therefore has no or little impact on the social contexts which people live in nor on society as a whole; through irony individuals can re-describe their life and re-create themselves, but this is a contingent and situated process that cannot be shared with other individuals. Thus, the ironist Rorty can look back at his adolescence and re-describe the scenes he has been involved in. However, the same scenes and the same scripts will be repeated over time if there is never a public and shared re-description of the roles of, and relationships between, classmates, which could be useful also to reframe the relationships between individuals and society. In these terms, confining irony to the private sphere means "restricting its corrosive power to the personal pursuit of autonomy" (Conway 1991: 198) and not letting it act in depth on the narratives and scripts that frame the social experience of individuals and communities. Scott Holland (2004), who explores Rorty's use of literature to find alternative tools to re-describe human experience, points out how his "fondness for the thrill of self-creation" (Holland 2004: 494) is the key to an understanding of the Rortyan vision of the relationship between individuals and society, which is also particularly significant from a pedagogical point of view. In particular, it is important to point out that at the root of the process of self-creation Rorty introduces a key element that requires an in-depth exploration. We can detect it in the passage of Trotsky and the Wild Orchids where Rorty points out that we are "just luckier, not more insightful, than the bullies with whom we struggle" (Rorty 1999: 15) since "we" - the individuals who have a shared understanding of the world as "liberal ironists" -, unlike the bullies, have had an opportunity to re-determine ourselves.

What Rorty calls "luck" is defined as an undetermined space within which education can make a difference, but always on an individual and private basis. Nicholas Rescher (2001 [1995]) describes "luck" as a "rogue force that prevents human life from being fully domesticated to rational management. Its foothold on the world stage is secure by the power of chance, chaos, and choice. Luck and her cousins, fate and fortune, make it somewhere between difficult and impossible to manage our lives successfully simply through planning and design" (Rescher 2001: 12) due to the fact that "our condition on the world's stage is the product of fate (what we are), of fortune (the conditions and circumstances in which we are placed), and of luck (what chances happen to us)" (Rescher 2001: 39). This understanding of the notion of luck is consistent with Rosa Calcaterra's (2019) analysis of Rortyan "contingentism" understood as "a conceptual net tied to the criteria of indeterminacy, ambiguity, uncertainty and randomness" (Calcaterra 2019: ix). "Luck" is, indeed, an "untranslatable" term. Gérald Sfez (2014) explains that it has been used over time to design "either chance, devoid of all intention, or the necessity of nature, that is to say the essential that with which human 'freedom of action' is concerned"; on these bases he moves on to name "the paradox of the relation between chance, necessity, and freedom in a manner that remains mythical without being a mystification" (Sfez 2014: 535). In literature, which is Rorty's most congenial cultural tool, "mythical" refers essentially to what Thomas Stearns Eliot in Ulysses, Order, and Myth (1923) describes as a "method," first acknowledged by Yeats, useful for the creation of a narrative order by using a peculiar "way of controlling, of ordering, of giving shape and significance to the immense panorama of futility and anarchy which is contemporary history" (Eliot 1923: 483), thereby making reference to the images and myths of the past. 
Similarly, Rorty uses the term "luck," which has a deep and dense cultural history, in accordance with a literary (non-philosophical) method, which helps him to give shape and meaning to the contingency of human experience, creating a narrative thread which can help individuals connect the past and present and make meaning of the present through the images of the past. This methodological choice deeply informs also Rorty's understanding of the role and function of education and his view of the educational process. In Contingency, Irony, and Solidarity Rorty highlights how individual experience can be understood in accordance with two different perspectives: a) a perspective deriving from western philosopical tradition which celebrates the individual capacity to "break out" of the world of time, appearance and idiosyncrasy and to reach a stable frame of reference identifiable in terms of "truth"; and b) a Nietzschian perspective which celebrates the capacity to escape from inherited descriptions of the contingencies of existence and to find new descriptive patterns. These two perspectives highlight how individuals are moved either by what Rorty defines as "a will to truth" or by a "will to self-overcoming" (Rorty 1989: 29). Accordingly, "the drama of an individual human life is not one in which a pre-existent goal is triumphantly reached or tragically not reached" following either a constant external reference or an "unfailing interior source of inspiration." Rather, it is "a process of Nietzschean self-overcoming" portrayed as a "dramatic narrative" whose paradigm is "the life of the genius" who "has found a way to describe that past which the past never knew, and thereby found a self to be which her precursors never knew was possible" (Rorty 1989: 29).

The genius, in Rorty's view, is not a particularly gifted individual who has innate qualities but someone who is sustained by a strong "will of self becoming," which is not a will to escape from, contrast or make fun of the cultural habits and traditions individuals are embedded in, but to re-use and re-invent them in a new and more meaningful way. This means that all individuals have the opportunity to be educated, but also that this depends on the contingent and "lucky" encounter of an individual with someone who, or something which, can sustain their process of growth. Within this framework Rorty refers to a specific sort of luck, the luck "which makes the difference between genius and eccentricity," describing it as a function of contingency, which is tightly interwoven with the individual capacity to move forward and the opportunities of "self overcoming" that individuals can grasp and use in the unfolding of their life experience.

This notion of "luck" is a key and recurring element in Rorty's educational discourse and contributes also to define the organization of the educational process, as we can see in Universality and Truth. Here, Rorty describes education, with a specific focus on college education, as a contextualist effort to help individuals become "participants" in a shared conversation through a systematic engagement with experiences leading to a process of "self-overcoming" which is facilitated by a specific form of "luck": the luck to have been involved in an educational experience, and sometimes to have been engaged in an educational relationship, that fosters the development of an ironic attitude. Therefore, he affirms that "students are lucky" to find themselves "under the benevolent Herrschaft [domination]" (Rorty 2000: 22) of a professor or a mentor who offers them the opportunity to "overcome themselves" in order to gain the ability to "re-describe" their experiences in different terms. But what is the role and function of Rorty's understanding of "luck" if we focus on the relationship between formative processes and educational experiences? Can we use the pattern inscribed within Rorty's 
notion of "luck" in order to understand the educational process in its mythical tension between the past and present, the cultural heritage and tradition, focusing on the possibility that individuals have to invent and re-describe their own traditions and vocabularies?

The cultural environment which individuals come from is always the first element that requires to be taken into account in order to understand the contingency of any educational experience within individual formative processes and to evaluate its impact in a long term perspective. As Jim Garrison points out, in Rorty's view "Education is the site of cultural reproduction" (Garrison 2001: 48) and this happens through a hermeneutic process emerging from the encounter with the narratives that represent the cultural and social traditions which individuals are exposed to. Nonetheless, we see that, in Rorty'sview, in order to be effectively educational, this process should be motivated not by a "will to truth" but rather by a "will to selfovercoming" - recalling the categories introduced by Rorty in Contingency, Irony, and Solidarity. Accordingly, education should therefore lead individuals and communities to be engaged as active participants in a cultural process which is not merely a process of the acquisition and reproduction of cultural references and values, but rather a process of the acquisition of cultural tools that the individuals can use to become active participants in a process of growth and change.

This vision of education is clearly an overcoming of the Platonic tradition that has been the main cultural reference for Western pedagogy and has deeply influenced the development of educational actions and practices. In Hermeneutics, General Studies, and Teaching (1982) Rorty tries to sketch a conception of education starting from Nietzschean rather than Platonic assumptions and describes the educational process as "participation in a community effort, learning to take a hand in what is going on, learning to speak more of the language which his time and place in history has destined him to speak" (Rorty 1982: 8). Therefore, each individual through education is engaged in the different cultural narratives which are providing her or him with references that should not be proposed as absolute truths, but rather as true statements acknowledged in a certain milieu and in a definite cultural and social context. This makes possible the emergence and contrasting of different statements and claims of truth, according to a vision consistent with Rorty's understanding of philosophy and of its relationship to politics and society.

In The Priority of Democracy to Philosophy (1992 [1984]), Rorty acknowledges the "priority" of democracy to philosophy asserting that the worry for freedom is more relevant than the worry for truth; accordingly, democracy should be understood as both the moral condition and the moral end of any educational project, since it is the grounding condition of the possibility of expressing oneself through different vocabularies and of being exposed to those vocabularies. As Rorty explains in Contingency, Irony, and Solidarity "truth is a property of sentences, since sentences are dependent for their existence upon vocabularies, and since vocabularies are made by human beings, so are truths" (Rorty 1989: 21). In this perspective the educational experience is what allows us to understand the infinite creative and re-creative potentialities of the human mind and its relationship with the social and political contexts within which it emerges.

For this reason, as Abellanosa points out, in a Rortyian perspective, even in the phase of socialization education is not "a process of helping us to get in touch with something 
non-human called Truth or Reality (other-worldly, objective, ultimate, unchanging) rather it is what keeps us in touch with our potentialities" and transforms itself, through the phase of individuation, into what Abellanosa has described as "the process of inventing something which will improve (Dewey pragmatic) our "tradition" (Gadamer hermeneutics), i.e. "what we have been told" (Abellanosa 2010: 98). Nonetheless, the possibility of inventing and re-describing one's own traditions and vocabularies is closely connected to the political conditions which allow or limit individuals in their capacity to imagine new conditions and new possibilities, which is not only a matter of ethical but also of esthetic judgment. "Truth" and "freedom," which are the Rortyan equivalents of heteronomy and autonomy, are the two constitutive elements of the educational process and should therefore be seen as part of an experiential continuum, to speak in Deweyan terms, and not as expressions of opposite narratives, as Rorty points out in Philosophy and Social Hope.

Here he tries to overcome the cultural and political dichotomy between the "right" and "left" visions of education, the former based on a Platonic and the latter on a Rousseauian and Marxist view, focusing on the idea that education is "the shaping of an animal into a human being by a process of socialization, followed (with luck) by the self-individualization and self-creation of that human being through his or her own later revolt against that very process" (Rorty 1999: 118). As Maria Virginia Machado Dazzani points out, in Rorty's view the two main aims of the educational enterprise are both to maintain one's own experiences and to determine one's own future (Machado Dazzani 2013) and they should be pursued in this order. However, as Rorty himself explains, in this process "socialization has to come before individuation, and education for freedom cannot begin before some constraints have been imposed" (Rorty 1999: 118), which occurs during the primary and secondary education period aimed at familiarizing the young with what their elders take to be true, whether it is true or not.

These constraints are cultural constraints, and are therefore contingent and historically determined by the different times and places which people are living in. This means that education cannot be conceived as existing outside a community, which is the context that holds and shares acknowledged descriptions of the world, keeps memories of previous descriptions and narratives, and constructs and negotiates "truths," including and legitimating new participants in the process of knowledge construction and transmission. The community is therefore the "public" space within which individual conscience and esthetic taste are formed through the socialization process within which students "take over the moral and political common sense of the society as it is" (Rorty 1999: 116).

Nonetheless, as Holland notes, Rorty is not a communitarian but he is rather "impatient with the excessive trend in the contemporary academy and society that celebrates group identity and identity politics" and considers questions such as "What culture do we come from? and What is our relation to that culture?" philosophically and educationally irrelevant. Since he is more interested in the politics of individuality, he acknowledges as more "edificant" the celebration of "Emersonian type stories," which "provide accounts of how people walked away from identification with this group or that community" and "use individual models to carve out a personal identity rather than turn to group mores to ask how the individual might find his plot and place in some collective identity" (Holland 2004: 500). Therefore, it makes a substantial difference whether or not an individual grows up in a democratic environment, since this determines how the process of "socialization" occurs, which discourses and values 
the individuals are exposed to, and which kind of vocabularies they learn to use in order to express their ideas and feelings.

Indeed, Rorty's vision of democracy is culturally grounded in the pragmatist, liberal and cultural milieu in which he grew up, as he explains in Philosophy and Social Hope. The United States allows US citizens to open "a prospect on illimitable democratic vistas" since the country is, according to Rorty "despite its past and present atrocities and vices, and despite its continuing eagerness to elect fools and knaves to high office" a "good example of the best kind of society so far invented" (Rorty 1999: 4). Accordingly, individuals who grow up there can have the opportunity to be exposed to discourses and narratives which shape their conscience according to a democratic ethos and their esthetic taste according to a narrative and shared understanding of individual and collective experience.

Nonetheless, this is a matter of a mixture of contingent elements that Rorty acknowledges as "luck." Contingency is therefore an original condition that leaves us open for different individual opportunities and spaces of socialization and, hopefully, of individuation. If it is true that it is the contingent condition of a human being that determines if one grows up in a moral community that shapes one's conscience and esthetic taste, it is also true that, according to Rorty, there are differences in the educational value of the socialiazation projects that the different moral communities undertake. Therefore, the acknowledgment of existing cultural differences does not justify the acknowledgment of a "cultural relativism" which would legitimate the educational validity of any kind of experience, discourse and narrative, even the most distorted and anti-democratic. Rorty's educational proposal is indeed an "ethnocentric" one, since he points out that what he acknowledges as "Our moral view" (democratic, liberal) is:

I firmly believe, much better than any competing view, even though there are a lot of people whom you will never be able to convert to it. It is one thing to say, falsely, that there is nothing to choose between us and the Nazis. It is another thing to say, correctly, that there is no neutral, common ground to which an experienced Nazi philosopher and I can repair in order to argue out our differences. That Nazi and I will always strike one another as begging all the crucial questions, arguing in circles. (Rorty 1999: 15)

The lack of this common ground depends not only on the lack of a shared cultural background, of shared narratives and "heroes," which as a consequence produces the impossibility of creating a common communicative space and of making equivalent use of the same vocabulary or even of constructing a new vocabulary but, before that, on the lack of a democratic moral foundation of individual and collective living as well on the lack of shared esthetic experiences.

It is at this point useful to note that Rorty's ethnocentrism cannot be assimilated to what is commonly understood as an uncritical faith in the superiority of one's home culture's beliefs, practices and institutions but, as Rorty points out in Objectivity, Relativism, and Truth (1991), it is a product of "the liberal culture of recent times" which is "open to encounters with other actual and possible cultures," and is willing to "make this openness central to its self-image." In so doing, it enhances its "ability to increase the freedom and openness of encounters, rather than [...] its possession of truth" (Rorty 1991: 2). In this perspective liberal culture, "constantly adding on more windows, constantly enlarging its sympathies," proposes itself as "a form of life which 
is constantly extending pseudopods and adapting itself to what it encounters. Its sense of its own moral worth is founded on its tolerance of diversity" (Rorty 1991: 204).

As a product of the process of socialization, according to this liberal ethnographic educational narrative, individuals are, as David Hildelbrand says, "acculturated but open" (Hildebrand 2003). In this perspective, Maximiliano Figueroa Muñoz sees ethnocentrism as "a condition to recognize and take into intercultural dialogue, an invitation to respect cultural difference and the task of managing it in order to turn it into a critical self-ethnocentrism and make it transferable to cultural influences that can generate relations of more solidarity" (Figueroa Muñoz 2016: 73). This perspective is also consistent with David Hansen's idea of an educational cosmopolitanism that includes a grounding "loyalty to the known" and a perspectival "openness to new" (cf. Hansen 2003). However, it has some specific connotations connected to a vision of the educational process, which may have different outcomes according to the success of its phases, within the framework of a very clear view of the human self as well as of the individual engagement in social life.

According to Rorty, the phase of socialization is followed by a phase of individuation, which can be seen as the second distinct and important element of the process that in Philosophy and the Mirror of Nature he had described as "edification," intended as "the project of finding new, better, more interesting, more fruitful ways of speaking" (Rorty 1979: 360); edification is indeed the final step of a lifelong project of the self-formation and re-creation of human beings intended as a contingent, centerless network of beliefs, desires and narratives. René Arcilla (1990), Carol Nicholson (1989) and Gert Biesta (1996) have discussed this idea of education as edification which occurs through conversation, as well as through a deeper and wider participation in multiple discourses and narratives.Within the current educational debate this idea is, indeed, very promising and useful in terms of overcoming current mainstream narratives but in my opinion there are some points that need to be discussed and clarified.

First of all, according to Rorty the phase of individuation, which not all individuals have the "luck" to be engaged in, is experienced during the college years which are aimed at offering "a provocation to self-creation" and therefore at helping students "realize they can reshape themselves" (Rorty 1999: 118), developing an increasingly critical, reflective and "ironic" attitude towards the world. Indeed, as Michael Bacon points out, this attitude is the ground on which to build an ironic process of selfcreation which plays also a social role "precisely by expanding logical space" (Bacon 2017: 961); moreover, as Christopher Voparil notes, irony "opens a space of freedom, choice, and responsibility that demands our own willed or self-chosen commitment" (Voparil 2016: 1) engaging individuals in a continuous conversation with the others and offering them "alternative perspectives from which to see things" which are precisely "what break the hold of our current, often unquestioned, lenses in order to bring the previously occluded into view" (Voparil 2016: 15).

In this process they learn to look at the world from a different perspective, and become capable of re-describing it in new and different terms; therefore, the process of reshaping individual life goes hand in hand with a process of "re-description" of the world and of the narratives which individuals are embedded in. As Paulo Ghilardelli Jr. (1999) points out, in this phase education can be seen as a process which sustains individuals in the elaboration of new ways of experimenting the world and of recreating it through the use of new languages, new vocabularies, new images and new 
metaphors within a complex dynamics of continuity, change and growth. But what happens to those individuals who do not have the opportunity to attend college? When and where does the process of individuation really start? Can it occur outside formal contexts or through other forms of relationship and engagement?

Undoubtedly, Rorty's educational proposal has the merit of defining a general framework within which it is possible to articulate or re-articulate the different dimensions of the educational process; nonetheless, compared to the complexity and reality of contemporary educational contexts within a globalized world, the process described requires to be enlarged and integrated, taking into account also the previous additional experiences that individuals gather within informal contexts and the complex interaction occurring between formal and informal contexts. Moreover, the educational process Rorty refers to represents what occurs, or should occur, within a particular kind of democratic society, according to an ethnocentric perspective. It is organized in such a way that the process of socialization, intended mainly as acculturation, is conceived as a phase, long lasting but preliminary, in the process of individual edification. This process occurs only if certain conditions hold: a) the individual has been exposed to cultural elements that can be potentially re-described since they are not proposed as truths but as sentences; b) individual freedom is preserved and cultivated; and c) the individual has the "luck" to be engaged in a process of edification. But what happens if none of these conditions are satisfied? Or if even one of them is not previously fulfilled? Certain individuals, from birth, in various different cultural and political contexts are embedded in informal or formal experiences of socialization which are not intended as a preliminary step to a subsequent process of individuation, but are conceived as totalizing, truth oriented and therefore lacking any premise for an authentic process of edification. Let us think, for example, of the child soldiers of the Camorra (the Neapolitan mafia), who are raised according to shared scripts and narratives within which negative "heroes" are identified as role models, and who grow up within discourses and vocabularies strongly connotated, which do not offer any space for re-interpretation or re-description. Let us think of the children born and raised within the Daesh Caliphate, who have been indoctrinated and exposed to discourses and narratives aimed at shaping and controlling, rather than edifying, their conscience. What chance do these children have of being engaged in a process of individuation and edification and where and when could this occur?

According to the framework designed by Rorty it seems to be almost impossible, unless they are, on an individual basis, "lucky" enough to escape from the cultural and historical context they live in and the narratives which they have been exposed to. In order to have the opportunity to develop a new vocabulary, they need, indeed, to be exposed to other languages and narratives and to encounter opportunities of "self overcoming" outside and beyond the socialization processes which they are engaged in. Tracy Llanera explains how Rorty's work can help "make sense of the interlocking features of truth, language, and solidarity that shape the life world" of this kind of individual and highlights the role of "redemptive relationships" which "attempt to capture the non-cognitive dimension of human encounter" (Llanera 2019: 20), thereby pointing out the essential role played by some kinds of relationship that have an educational role since they offer individuals the possibility to look at their own experience from a different perspective. We should bear in mind that the formative process unfolds at different levels and in different domains of human experience, 
involving multiple actors, times and spaces. Accordingly, from a pedagogical point of view, we should not look at the process of edification as circumscribed and separated within a defined time and space; it is, instead, necessary to explore the conditions that may allow all individuals, even those who do not seem to have the opportunity to escape from the narratives which they are involved in, to engage in a process of selfdisclosure, self-discovery, self-understanding and self-determination, in any dimension and at any moment of the formative process. This requires a focus on the potentially edifying opportunities that may function as potential hidden triggers of a "will of overcoming," as well as on the multiple and various relationships that constitute the texture of individual experience in order to detect the educational potential embedded within it, and to envisage the possible trajectories of edification that each individual could be engaged in. We should also consider that the outcomes of the process of socialization are crucial in the definition of the possibility of individual edification and, therefore, we cannot separate them from the process of individuation.

On this basis, I agree with Robert Reich who does not see the reason why the process of socialization must be separate and distinct from the process of individuation. "Why could they not, for example, proceed simultaneously and co-exist within a continuous project, just as liberalism and irony co-exist within Rorty's utopian community? Rorty unfairly and arbitrarily limits the process of individuation to colleges and universities. In doing so, he undermines the effect and drastically limits the scope of the “"provocation to self-creation' so crucial to his liberal utopia" (Reich 1996: 346). This is also the opinion of Khosrow Bagheri Noaparast (2014) who points out that Rorty's "dichotomy" between socialization and edification "makes edification impossible to achieve unless there can be a relation between the two phases of education" (Bagheri Noaparast 2014: 98). If the process of individuation unfolds as a process of redescription and discovery of new possibilities of individual and collective life, this opportunity should be offered to each and every individual from the very beginning of the educational project and within different educational contexts, formal, non-formal and informal, also taking into account the fact that not every project unfolds according to a linear perspective that leads to formal higher education.

Rorty acknowledges the educational value of multiple and different educational experiences and of the exposure to multiple cultural stimuli, and encourages individuals to move around the cultural bazaar offered by our contingent world. However, he does not clearly point out how it might be possible to integrate these experiences into a continuous and comprehensive educational project within which each and every one could have equal opportunities to grow. This requires a re-framing of the individual process of edification, which - in order be effective and generative should not be understood only as a private experience, but also as a public reference for other individuals.

This is consistent with Rorty's idea of social development as a process guided by "instructive" stories to share, as he points out in Justice as a Larger Loyalty, rather than rational norms, principles and values mastered by a "universal human capacity" (Rorty 1997: 147). An educational project inscribed within this vision of social growth is described in Human Rights, Rationality and Sentimentality, where the American philosopher highlights the necessity of taking into account the fact that some people "were not so lucky in the circumstances of their upringing" since they have been "deprived" of "security and sympathy" which are essential conditions to foster individual and collective projects of edification. Again, Rorty uses the term "luck" to 
describe a specific and crucial educational condition, which I believe represents a challenge for a democratic society, within which everybody has the right to be "lucky." This means that in a democratic society there should not be deprived and "lucky" individuals or, at least, there should always be the opportunity for all to overcome deprived life conditions. The only way to engage both "deprived" and "lucky" individuals in a unified educational project is to inscribe them within a broader process of social development, aimed at acknowledging and reducing the conditions of deprivation, and cultural and social change according to shared instances and hopes, overcoming the distinction between the private and public dimensions of human experience. This requires the reference to a peculiar educational narrative that can effectively make use of what Rorty calls "sentimental education," whose aim is to develop in each individual an increasing capacity to see similarities beyond differences, which can be fostered through a deep engagement in a variety of life stories, that contribute to the creation of new shared narratives and vocabularies (Rorty 1998: 128). If the role of education is to determine luckier upbringing conditions for a wider number of individuals and communities, this may occur only on the basis of the creation of a shared space of understanding within which the public encounter with private stories of edification can sustain a reflective acknowledgment of the contingency of the human experience, and a shared commitment to enhance the "will of overcoming" both for individuals and for the communities they live in, which is the basis of any democratic society.

\section{BIBLIOGRAPHY}

ABELLANOSA Rhoderick John S., (2010), “Rorty's Philosophy of Education: Between Orthodoxy and Vulgar Relativism," Kritike, 4 (2), 87-104.

ARCILla René V., (1990), "Edification, Conversation, and Narrative: Rortyan Motifs for Philosophy of Education," Educational Theory, 40 (1), 35-39.

ARCILla René V., (1993), “Contingency in Rorty's Philosophy," Studies in Philosophy and Education, 12 (2-4), 201-3.

BACON Michael, (2017), "Rorty, Irony and the Consequences of Contingency for Liberal Society," Philosophy and Social Criticism, 43 (9), 953-65.

BAGHERI NOAPARAST Khosrow, (2014), "Richard Rorty's Conception of Philosophy of Education Revisited," Educational Theory, 64, 1, 75-98.

BERNSTEIN Richard, (1992), The New Constellation: The Ethical-political Horizons of Modernity/ Postmodernity, Boston, The MIT Press.

BIESTA Gert, (1996), “Education, Not Initiation," in Frank Margonis (ed.), Philosophy of Education Society Yearbook, Urbana, Illinois, ("Philosophy of Education Society"), 90-8. 
CALCATERRA Rosa Maria, (2015), “Chance and Regularities: Remarks on Richard Rorty's

Contingentism," European Journal of Pragmatism and American Philosophy, VII-2, 1-10.

[journals.openedition.org/ejpap/417].

CALCATERRA Rosa Maria, (2019), Contingency and Normativity. The Challenges of Richard Rorty, Brill,

Rodopi.

CASSIN Barbara, APTER Emily, LEZRA Jacques \& Michael wOOD (eds.), (2014), Dictionary of

Untranslatables: A Philosophical Lexicon, Princeton, Princeton University Press.

CoNwAY Daniel, (1991), “Taking Irony Seriously: Rorty's Post-Metaphysical Liberalism,” American

Literary History, 3 (1) (Spring), 198-208.

DIELEMAN Susan, (2010), "Revisiting Rorty: Contributions to a Pragmatist Feminism," Hypatia, 25

(4) (Fall), 891-908.

ELLIOT Thomas Stearns, (1923), “Ulysses, Order, and Myth,” The Dial, 75 (Nov.), 480-3.

FIGUEROA MUÑOZ Maximiliano, (2016), "Ethnocentrismo Critico y Solidariedad," Erasmus, XVIII, 1/2016, 73-92.

GARRISON Jim, (2001), "Rorty, Methaphysics, and the Education of Human Potential," in M. A. Peters \& P. Ghiraldelli Jr. (eds.), Richard Rorty. Education, Philosophy and Politics, Boulder, CA, Rowman \& Littlefield Publishers, 47-66.

GHILARDELLI Jr. Paulo, (1999), Richard Rorty: a filosofia do novo mundo em busca de mundos novos, Centro, Petrópolis, Editora Vozes.

HABERMAS Jürgen, (1990 [1983]), Moral Consciousness and Communicative Action, translated by Christian Lenhardt and Shierry Weber Nicholsen, introduction by Thomas A. McCarthy, Cambridge, Massachusetts, The MIT Press.

HALIBURTON Rachel, (1997), "Richard Rorty and the Problem of Cruelty," Philosophy and Social Criticism, 23 (1), 49-69.

HILDEBRAND David Louis, (2003), "Neopragmatism and the Relativist Menace," Presentation to University of Colorado Denver Philosophy Department, Speaker Series, September 10.

HOLLAND Scott, (2004), "The Coming only is Sacred. Self-Creation and Social Solidarity in Richard Rorty's Secular Eschatology," Cross Currents, 53 (4), 494-510.

KYUNG-MAN Kim, (2014), "Beyond Justification, Habermas, Rorty and the Politics of Cultural Change," Theory, Culture \& Society, 31 (6), 103-23.

LLANERA Tracy, (2016), "Redeeming Rorty's Private-Public Distinction," Contemporary Pragmatism, 13 (3), 319-40.

LLANERA Tracy, (2019), "Disavowing Hate: Group Egotism from Westboro to the Klan," Journal of Philosophical Research, 44, 13-31.

MACHADO DAZZANI Maria Virginia, (2013), Rorty \& a Educação, Belo Horizonte- São Paulo, Grupo Autêntica.

MILLER Christian B., (2002), "Rorty and Moral Relativism," European Journal of Philosophy, 10, 354-74.

NICHOLOSON Carol, (1989), "Postmodernism, Feminism, and Education: The Need for Solidarity," Educational Theory, 39 (3), 197-205. 
PETERS Michael A. \& Paulo GHIRALDELli Jr., (2001), Richard Rorty. Education, Philosophy and Politics, Boulder, CA, Rowman \& Littlefield Publishers.

PORCHEDDU Alba, (2002), "Richard Rorty e il romanzo come formazione," in F. Cambi (ed.), La ricerca educativa nel neopragmatismo americano, Roma, Armando Editore.

REICH Robert, (1996), “The Paradoxes of Education in Rorty's Liberal Utopia," in Frank Margonis (ed.), Philosophy of Education, Urbana, IL, ("Philosophy of Education Society”), 342-51.

RESCHER Nicholas, (2001 [1995]), Luck: The Brilliant Randomness of Everyday Life, Pittsburgh, University of Pittsburgh Press.

RORTY Richard, (1979), Philosophy and the Mirror of Nature, Princeton, Princeton University Press. RORTY Richard, (1989), Contingency, Irony, and Solidarity, Cambrige, Mass., Cambridge University Press.

RORTY Richard, (1990), “The Dangers of Over-Philosophication: Reply to Arcilla and Nicholson,” Educational Theory, 40 (1), 41-4.

RORTY Richard, (1991), Obiectivity Relativism, and Truth, Cambridge, Mass., Cambridge University Press.

RORTY Richard, (1992 [1984]), “The Priority of Democracy to Philosophy," in John P. Reeder \& Gene Outka (eds.), Prospects for a Common Morality, Princeton, Princeton University Press, 254-78.

RORTY Richard, (1992), "Trotsky and the Wild Orchids," Common Knowledge, 1 (3), 140-53. Reprinted in Philosophy and Social Hope, London, Penguin Books, 1999.

RORTY Richard, (1997), “Justice as a Larger Loyality,” Ethical Perspectives, 4 (2), 139-51.

RORTY Richard, (1998), "Human Rights, Rationality, and Sentimentality," Truth and Progress, Cambridge, Cambridge University Press.

RORTY Richard, (1999), Philosophy and Social Hope, London, Penguin Books.

RORTY Richard, (2000), "Universality and Truth," in Robert B. Brandom (ed.), Rorty and His Critics, Oxford, Blackwell, 1-30.

RORTY Richard, (2010), “Intellectual Autobiography," in Randall E. Auxier \& Lewis Edwin Hahn (eds.), The Philosophy of Richard Rorty, XXXII, Chicago, Open Court, 21-2.

RORTY Richard \& C. Barry СНАВОT, (1982), Richard Rorty on Hermeneutics, General Studies, and Teaching: with Replies and Applications, Fairfax, Va., George Mason University.

SFEZ Gérald, (2014), "Fortuna in the Renaissance," in B. Cassin, E. Apter, J. Lezra \& M. Wood (eds.), Dictionary of Untranslatables: A Philosophical Lexicon, Princeton, Princeton University Press, 535. VOPARIL Christopher J., (2016), "Rorty and James on Irony, Moral Commitment, and the Ethics of Belief," William James Studies, 12 (2), 1-27.

\section{ABSTRACTS}

Starting from an emblematic episode described by Rorty in Trotsky and the Wild Orchids, which is an effective narrative example of making public a private experience, the article provides an inquiry into Rorty's thinking around education, with a particular focus on his notions of contingency and luck.In particular, the article offers an analysis of Rorty's frequent use of the term "luck," in accordance with a literary (non-philosophical) method, which informs his 
understanding of the role and function of education and his view of the educational process. The use of a literary method is useful to give shape and meaning to the contingency of human experience, creating a narrative thread to connect the past and present and make meaning of the present through the images of the past. Within this framework, Rorty understands "luck" as a specific and crucial condition that highlights the presence of an undetermined space within which education can make a difference in individual life.

\section{AUTHOR}

\section{MAURA STRIANO}

Università degli Studi di Napoli Federico II

maura.striano[at]unina.it 